\title{
Darriwilian (Middle Ordovician) conodonts and graptolites from the Cerro La Chilca Section, Central Precordillera, Argentina
}

\author{
*Fernanda Serra ${ }^{1,2}$, Nicolás A. Feltes ${ }^{1,2}$, Matías Mango ${ }^{1,2}$, \\ Miles A. Henderson ${ }^{3}$, Guillermo L. Albanesi ${ }^{1,2,4}$, Gladys Ortega ${ }^{4}$ \\ ${ }^{\prime}$ Facultad de Ciencias Exactas, Físicas y Naturales (FCEFyN), Universidad Nacional de Córdoba (UNC), Av. Vélez Sarsfield 299, \\ X5000 JJC, Córdoba, Argentina. \\ 2 Consejo Nacional de Investigaciones Científicas y Técnicas (CONICET), Centro de investigaciones en Ciencias de la Tierra, \\ (CICTERRA), Av. Vélez Sarsfield 1611, Córdoba, Argentina. \\ fserra@unc.edu.ar;nfeltes@unc.edu.ar; matiasjmango@gmail.com \\ ${ }^{3}$ Department of Geosciences, University of Texas Permian Basin, 4901 E University Blvd. Odessa, TX 79762, United States. \\ henderson_m@utpb.edu \\ ${ }^{4}$ CONICET-Museo de Paleontología, CIGEA, FCEFyN, UNC, Av. Vélez Sarsfield 297, Córdoba, Argentina. \\ guillermo.albanesi@unc.edu.ar; gladyscortega@gmail.com \\ *Corresponding author:fserra@unc.edu.ar
}

\begin{abstract}
The Ordovician System is extensively represented in the Precordillera of San Juan Province, Argentina. At the Cerro La Chilca in the Jáchal area, the limestone of the San Juan Formation is paraconformably overlain by interbedded limestone and shale of the Gualcamayo Formation. The present contribution reports new data on the conodont fauna and biostratigraphy of these darriwilian units, revising local and regional chronostratigraphic relationships. New information on the composition of conodont and graptolite associations through the stratigraphic sequence is presented. The presence of Paroistodus horridus horridus, Yangtzeplacognathus crassus, and Histiodella sinuosa constrain the uppermost strata of the San Juan Formation to the lower part of the Y. crassus Zone, according to the Baltoscandian scheme, and to the H. sinuosa Subzone of the Periodon macrodentatus Zone of the North American scheme. In the overlying Gualcamayo Formation the co-occurrence of $Y$. crassus with Histiodella holodentata enable the recognition of the $Y$. crassus Zone and the H. holodentata Subzone of the P. macrodentatus Zone. The identification of these zones allows for precise global and regional correlation. A graptolite assemblage that belongs to the epipelagic and deep-water biotopes with some components restricted to low paleolatitudes is recognized. This diverse assemblage is characteristic of the pelagic biofacies. The important diversity of graptolites in this section suggests a favorable environment for their development. Local changes in the taxonomic composition are recognized through the Gualcamayo Formation. When comparing this fauna with that of different study localities from the Central Precordillera (Cerro Potrerillo, Oculta Creek, Cerro Viejo de Huaco and Las Aguaditas Creek) slight differences in the generic composition are observed. Taxonomic differences support the preference of certain associations for particular environments; though, graptolites are more diverse in black shales facies, which represent deeper environments (the Los Azules Formation), in relation to the calcareous-shale facies of the Gualcamayo Formation from Cerro La Chilca and correlative unit at Las Aguaditas Creek.
\end{abstract}


RESUMEN. Conodontes y graptolitos darriwilianos (Ordovícico Medio) del Cerro La Chilca, Precordillera Central, Argentina. El Sistema Ordovícico se encuentra ampliamente representado en la Precordillera de la Provincia de San Juan, Argentina. En el cerro La Chilca, área de Jáchal, las calizas de la Formación San Juan infrayacen de manera paraconcordante a las calizas y lutitas de la Formación Gualcamayo. En este trabajo se brindan nuevos antecedentes sobre la bioestratigrafía de conodontes de estas unidades estratigráficas darriwilianas y se revisa su correlación cronoestratigráfica a nivel local y regional. Adicionalmente, se reportan nuevos datos sobre la composición de la asociación conodontes-graptolitos a lo largo de esta secuencia estratigráfica. La presencia de Paroistodus horridus horridus, Yangtzeplacognathus crassus e Histiodella sinuosa restringen los estratos cuspidales de la Formación San Juan a la parte inferior de la Zona de Y. crassus, según el esquema Báltico, y Subzona de H. sinuosa (Zona de Periodon macrodentatus) del esquema norteamericano. En la suprayacente Formación Gualcamayo la coexistencia de Y. crassus con Histiodella holodentata permite identificar la Zona de $Y$. crassus y la Zona de Periodon macrodentatus (Subzona de H. holodentata) para esta unidad. Estas zonas permiten realizar una correlación bioestratigráfica precisa a escala regional y global. A su vez, se reconoce una asociación de graptolitos perteneciente a los biotopos epipelágicos y de aguas profundas con algunos componentes de paleolatitudes bajas. Esta diversa asociación es característica de la biofacies pelágica. La gran riqueza y abundancia de graptolitos en esta sección sugiere un ambiente favorable para su desarrollo. Se observan cambios locales en la composición taxónomica de este grupo a través de la Formación Gualcamayo. Al comparar esta graptofauna con la documentada en otras secciones estratigráficas de la Precordillera Central (cerro Potrerillo, quebrada Oculta, Cerro Viejo de Huaco y quebrada de Las Aguaditas) se observan diferencias en la composición genérica de graptolitos. Esto sugiere una preferencia a determinados ambientes; de modo que, los graptolitos son más diversos en las facies pelíticas que representan ambientes más profundos (Formación Los Azules), en relación a las facies calcáreo-pelíticas de las formaciones Gualcamayo en el cerro La Chilca y quebrada Las Aguaditas.

Palabras clave: Conodontes, Bioestratigrafia, Graptolitos, Ordovícico Medio, Precordillera Argentina.

\section{Introduction}

The Precordillera is a geological province located in the western margin of Argentina, between the Frontal Cordillera to the West and the Pampean Range to the East, covering parts of La Rioja, Mendoza and San Juan provinces (Stelzner, 1873; Furque and Cuerda, 1979; Baldis et al., 1982). It is characterized by a $\sim 2,000 \mathrm{~m}$ thick succession of Cambrian-Ordovician sedimentary rocks preserved in an extensive fold-andthrust orogenic belt (Astini et al., 1996). In the Jáchal area of San Juan Province, Lower Paleozoic strata are extensively exposed and have been the subject of many paleontological and geological investigations (e.g., Benedetto, 2003 and references therein). An important Ordovician exposure is represented in the Cerro La Chilca section, located approximately $40 \mathrm{~km}$ south of San José de Jáchal, in the San Juan Province, Argentina (Fig. 1).

The pioneering work of Stappenbeck (1910) was followed by numerous contributions on the geology, stratigraphy, and paleontology of the sedimentary rocks exposed in this area (e.g., Cuerda, 1965, 1973, 1986; Blasco and Ramos, 1976; Furque, 1983; Sánchez et al., 1996; Astini and Benedetto, 1992; Astini and Maretto, 1996; Benedetto, 2010; Ortega et al., 2013).

Several contributions tackled the biostratigraphy of this section by studying the conodonts, trilobites and graptolites in these Ordovician rocks (e.g., Lehnert, 1995; Peralta et al., 2003; Tortello and Peralta, 2004; Mestre, 2012; Serra et al., 2017). However, the graptolite and conodont fauna previously documented in the San Juan and Gualcamayo formations have been revised (Löfgren and Zhang, 2003; Serra et al., 2017; Serra et al., 2019); thus, an updated biostratigraphy for these units is needed. This contribution reports new data on the conodont fauna from the uppermost part of the San Juan Formation and the Gualcamayo Formation. Regional and global chronostratigraphic relationships are provided with a thorough revision of the conodont biostratigraphy. Also, new information on the composition of conodont and graptolite associations through the rock succession is presented, including the description of the diverse graptolite assemblage documented by Serra et al. (2017).

\section{Cerro La Chilca section}

\subsection{Geologic framework}

The Ordovician succession that crops out in this area consists of the San Juan (upper Tremadocianlower Darriwilian), Gualcamayo (middle Darriwilian), Los Azules (lower Sandbian) and Don Braulio (Hirnantian) formations (Baldis et al., 1982; Peralta, 2003). These units are successively overlain by the 


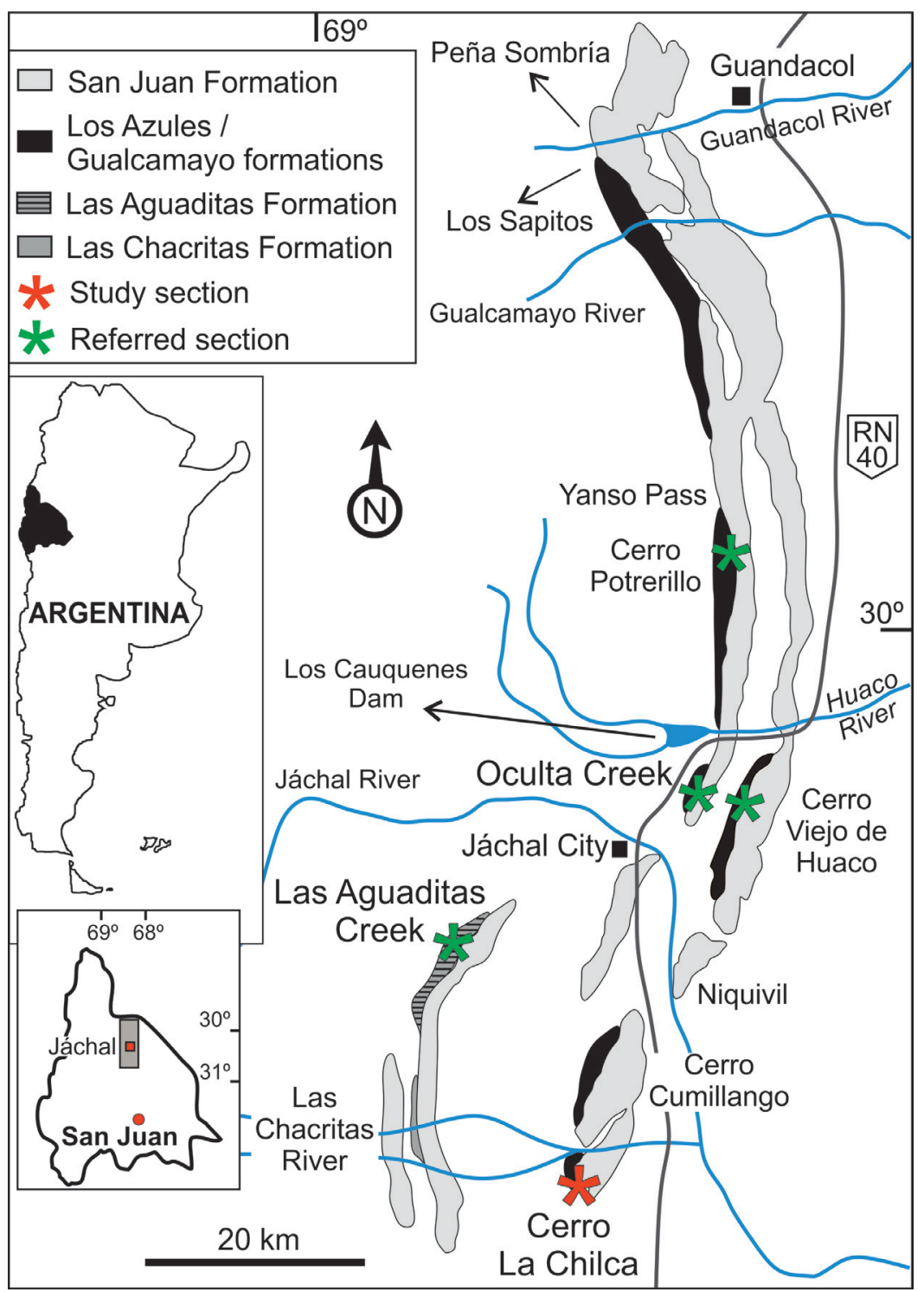

FIG. 1. Location map of the Cerro La Chilca section and reference sections from the Precordillera of San Juan Province.

La Chilca and Los Espejos formations of mostly Silurian age (Cuerda, 1969) and the Talacasto (Padula et al., 1967) and Punta Negra (Bracaccini, 1950) formations of Devonian age (Cuerda and Furque, 1985; Cuerda, 1986; Astini and Benedetto, 1992).

The Ordovician rock sequence described by Cuerda (1965) at the Cerro La Chilca section was recognized as the San Juan and the Los Azules Formations (Furque, 1983; Cuerda, 1986). Later, the succession of interbedded shale and siltstone, overlying the San Juan Formation at this locality, was described by Astini and Benedetto (1992) as the Gualcamayo Formation and interpreted as transgressive deposits. These authors divided the Gualcamayo Formation into two members, equivalent respectively to the upper San Juan Formation sensu Cuerda (1986) and to the Los Azules Formation as previously identified by Furque (1983).

More recently, Peralta (1998) and Tortello and Peralta (2004) described the lower part of the Gualcamayo Formation at Cerro La Chilca as a $4.3 \mathrm{~m}$ thick unit with alternation of black, tabular marly 
limestones and dark laminated shales that overly the limestone of the San Juan Formation. The uppermost fossiliferous level of black limestone defines the upper-limit of the Gualcamayo Formation, which is unconformably overlain by the shaly Los Azules Formation (Peralta, 1998); formerly described as the upper member of the Gualcamayo Formation by Astini and Benedetto (1992). The Los Azules Formation consists of $78 \mathrm{~m}$ of black shales with occasional intercalations of lensoidal beds of dark limestones. A significant hiatus corresponding to the Guandacolic orogeny occurs between these units (Peralta, 2003).

In the present contribution, only the top strata of the San Juan Formation and the Gualcamayo Formation are analyzed. The former is characterized by $20 \mathrm{~cm}$ thick skeletal wackestones beds, which present a light gray to ochre color on weathered surfaces and dark gray in freshly broken planes. The Gualcamayo Formation, $c a .4 \mathrm{~m}$ in thickness, consists of 10-20 cm thick carbonate mudstones interbedded with black shales (Fig. 2). The Gualcamayo shales are light brown when weathered and black in fresh exposure surfaces, graptolite remnants are common on shale bedding planes.

\subsection{Paleontological framework}

Several paleontologic studies have been carried out in the Cerro La Chilca locality. For instance, conodont, sponge, bryozoan, and crinoid assemblages have been described for the uppermost part of the San Juan Formation (e.g., Lehnert, 1995; Sánchez et al., 1996; Carrera, 1997; Keller, 1999; Mestre, 2012; Carrera et al., 2013; Serra et al., 2017). In a recent contribution, graptolites were documented for the first time in the uppermost part of the formation, $c a .1 \mathrm{~m}$ below its contact with the Gualcamayo Formation (Serra et al., 2017).

In the upper part of the San Juan Formation and the overlying Gualcamayo Formation, Mestre (2012) documented the presence of Eoplacognathus pseudoplanus (Viira), Histiodella kristinae (Stouge) and Microzarkodina sp. cf. M. ozarkodella (Lindström),
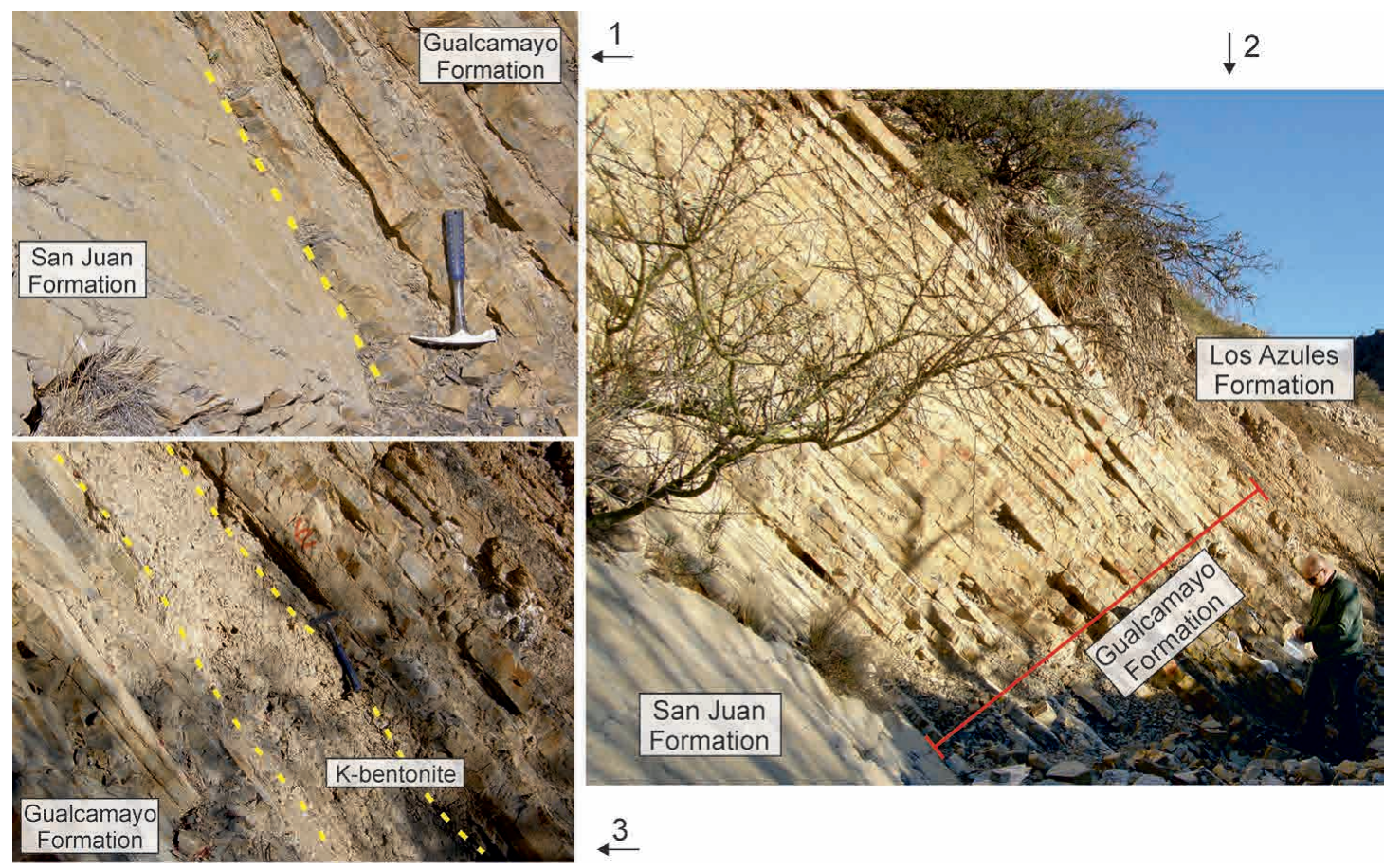

FIG. 2. Cerro La Chilca section. 1. Detail of the contact between the San Juan and the overlying Gualcamayo formations. 2. Detail of the study section (view to the SE): Top stratum of the San Juan Formation; $4 \mathrm{~m}$ thickness of the Gualcamayo Formation showing its characteristic chalcareous-shaly lithology; Los Azules Formation of Sandbian age overlying the Gualcamayo Formation. 3. $25 \mathrm{~cm} \mathrm{~K}$-bentonite layer (graptolite sample F) of the Gualcamayo Formation. 
suggesting the presence of the upper E. pseudoplanus Zone in the contact between these formations. The identification of the E. pseudoplanus Zone at the top of the San Juan Formation at Cerro La Chilca has been questioned by recent studies (Carrera et al., 2013; Serra et al., 2017), which revise the age according to the presence of $H$. sinuousa.

Sclerites of plumulitids were recorded in the Gualcamayo Formation, representing the first record of machaeridians in Argentina (Benedetto, 2010; Ortega, 2010; Ortega et al., 2013). In this formation a rich trilobite assemblage, characteristic of the Kainisiniella cuyana Zone, was documented. The referred assemblage is dominated by Mendolaspis salagastensis Rusconi, whereas Geragnostus sp., Neptunagnostella superb Shergold, Porterfieldia sp., Nileusdepressus argentinensis Tortello and Peralta, Carolinites latus Tortello and Peralta, Carolinites aff. pardensis Legg, and Macrogrammus pengi Edgecombe, Chatterton, Vaccari and Waisfeld are barely recorded (Tortello and Peralta, 2004). This formation also bears a rich graptolite fauna that consists of Acrograptus sp., Holmograptus bovis Williams and Stevens, Xiphograptus lofuensis Lee, Pseudobryograptus parallelus $\mathrm{Mu}$, Thamnograptus? sp., Jiangshanites? sp., Pseudophyllograptus sp., Tetragraptus bigsbyi (Hall), T. quadribrachiatus (Hall), Arienigraptus zhejiangensis Yu and Fang, Parisograptus caduceus (Salter), Glossograptus sp., Paraglossograptus tentaculatus (Hall), Levisograptus austrodentatus (Harris and Keble), L. dentatus (Brongniart), L. primus (Legg) and L. sinicus (Mu and Lee), a particular assemblage that corresponds to the L. dentatus Zone (Serra et al., 2017).

\section{Materials and methods}

A total of 13 samples were collected (Fig. 3), including 5 samples from the upper part of the San Juan Formation and 8 from the Gualcamayo Formation. The samples of $2 \mathrm{~kg}$ each were digested in a $10 \%$ acetic acid solution, according to the method described by Stone (1987). The conodont elements picked up account for a total of 971 identifiable specimens (Table 1). These exhibit a color alteration index (CAI) of 2.5, reflecting burial paleotemperatures between $90^{\circ} \mathrm{C}$ and $110^{\circ} \mathrm{C}$ (Epstein et al., 1977). The graptolite fauna from the Cerro La Chilca section was referred in a recent study (Serra et al., 2017), where it was dealt for biostratigraphic purposes; whereas in the present paper a palaeoenvironmental appraisal is given to this fauna.

The fossil collection is housed in the Museo de Paleontología, Facultad de Ciencias Exactas, Físicas y Naturales, Universidad Nacional de Córdoba, under the repository codes CORD-MP, for conodonts, and CORD-PZ, for graptolites.

\section{Biostratigraphy}

\subsection{Conodont fauna}

A diverse conodont association was recovered from the study section, including the following species (Figs. 3, 4, 5): Ansella jemtlandica (Löfgren), A. sinuosa (Stouge), Baltoniodus clavatus Stouge and Bagnoli, "Bryantodina" aff. typicalis (Stauffer), Coelocerodontus bicostatus van Wamel, Cornuodus longibasis (Lindström), Costiconus ethingtoni (Fåhræus), Dapsilodus sp., Decoriconus pesequus Löfgren, Drepanoistodus sp. Drepanoistodus bellburnensis Stouge, D. tablepointensis Stouge, Drepanodus arcuatus Pander, D. reclinatus (Lindström), Erraticodon alternans (Hadding), Fahraeusodus jachalensis Feltes and Albanesi, Histiodella serrata Harris, H. sinuosa, H. holodentata, Juanognathus jaanussoni Serpagli, Microzarkodina hagetiana (Stouge and Bagnoli), Parapaltodus simplicissimus Stouge, Paraprioniodus costatus (Mound), Paroistodus horridus Barnes and Poplawski, P. horridus secundus Albanesi, P. originalis (Sergeeva), Periodon macrodentatus, Polonodus sp. Protopanderodus gradatus Serpagli, Pteracontiodus cryptodens (Mound), Rossodus barnesi Albanesi, Scolopodus striatus (Lindström), and Semiacontiodus potrerillensis Albanesi and Yangtzeplacognathus crassus (Chen and Zhang).

This species assemblage and the presence of key index taxa such as $Y$. crassus, $H$. sinuosa and $H$. holodentata, constrain the contact between the San Juan and Gualcamayo formations to the $Y$. crassus Zone as defined for the Baltoscandian region (assessed by Löfgren and Zhang, 2003) and to the $H$. sinuosa and $H$. holodentata subzones of the P. macrodentatus Zone following the scheme of Stouge (2012) for western Newfoundland (Fig. 6). The cooccurrence of Paroistodus horridus horridus with $Y$. crassus identifies the base of the $Y$. crassus Zone at the top of the San Juan Formation. This conodont zonal determination agrees with the identification of 


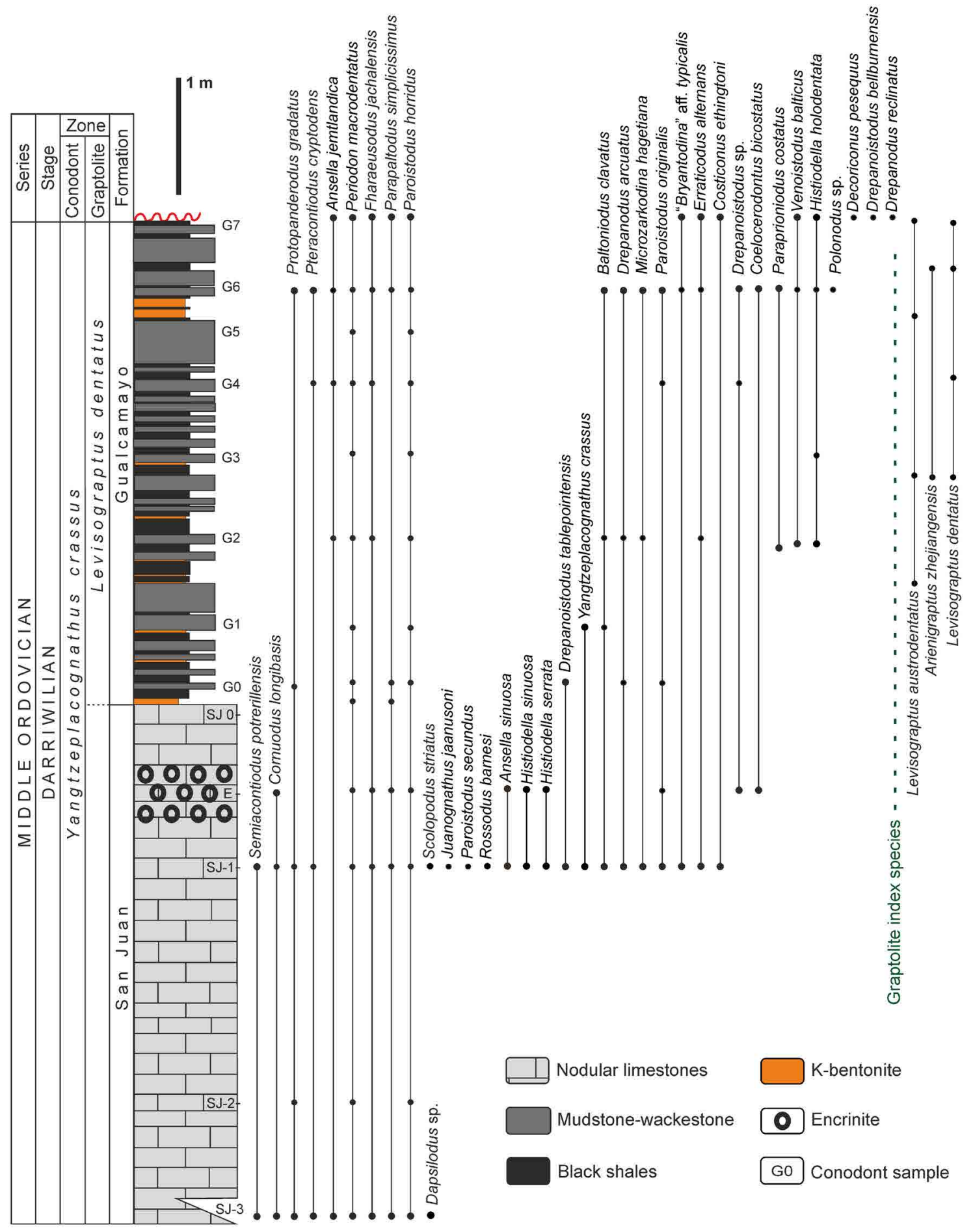

FIG. 3. Stratigraphic column showing conodont and key graptolite species ranges of the San Juan and Gualcamayo formations in the Cerro La Chilca section. 
TABLE 1. CONODONT OCCURRENCE AND ABUNDANCE DATA FROM THE SAN JUAN AND THE GUALCAMAYO FORMATIONS AT THE CERRO LA CHILCA SECTION.

\begin{tabular}{|c|c|c|c|c|c|c|c|c|c|c|c|c|c|}
\hline \multirow[b]{2}{*}{ Species } & \multicolumn{13}{|c|}{ Samples } \\
\hline & SJ-3 & SJ-2 & SJ-1 & $\mathbf{E}$ & SJ0 & G0 & G1 & G2 & G3 & G4 & G5 & G6 & G7 \\
\hline Ansella jemtlandica & 1 & 0 & 8 & 0 & 0 & 0 & 0 & 1 & 0 & 2 & 0 & 23 & 7 \\
\hline Ansella sinuosa & 0 & 0 & 2 & 8 & 0 & 0 & 0 & 0 & 0 & 0 & 0 & 0 & 0 \\
\hline Baltoniodus clavatus & 0 & 0 & 1 & 0 & 0 & 0 & 1 & 2 & 0 & 0 & 0 & 2 & 0 \\
\hline "Bryantodina" aff. typicalis & 0 & 0 & 1 & 0 & 0 & 0 & 0 & 0 & 0 & 0 & 0 & 4 & 1 \\
\hline Coelocerodontus bicostatus & 0 & 0 & 0 & 2 & 0 & 0 & 0 & 0 & 0 & 0 & 0 & 1 & 0 \\
\hline Cornuodus longibasis & 1 & 0 & 1 & 2 & 0 & 0 & 0 & 0 & 0 & 0 & 0 & 0 & 0 \\
\hline Costiconus ethingtoni & 0 & 0 & 3 & 0 & 0 & 0 & 0 & 0 & 0 & 0 & 0 & 0 & 2 \\
\hline Dapsilodus sp. & 0 & 0 & 2 & 0 & 0 & 0 & 0 & 0 & 0 & 0 & 0 & 0 & 0 \\
\hline Decoriconus pesequus & 0 & 0 & 0 & 0 & 0 & 0 & 0 & 0 & 0 & 0 & 0 & 0 & 2 \\
\hline Drepanodus arcuatus & 0 & 0 & 6 & 0 & 0 & 1 & 0 & 1 & 0 & 0 & 0 & 2 & 0 \\
\hline Drepanodus reclinatus & 0 & 0 & 0 & 0 & 0 & 0 & 0 & 0 & 0 & 0 & 0 & 0 & 2 \\
\hline Drepanoistodus sp. & 0 & 0 & 0 & 5 & 0 & 0 & 0 & 0 & 0 & 3 & 0 & 2 & 0 \\
\hline Drepanoistodus bellburnensis & 0 & 0 & 0 & 0 & 0 & 0 & 0 & 0 & 0 & 0 & 0 & 0 & 1 \\
\hline Drepanoistodus tablepointensis & 0 & 0 & 9 & 0 & 0 & 1 & 0 & 0 & 0 & 0 & 0 & 0 & 0 \\
\hline Erraticodon alternans & 0 & 0 & 1 & 0 & 0 & 0 & 0 & 1 & 0 & 0 & 0 & 1 & 1 \\
\hline Fahreusodus jachalensis & 1 & 0 & 6 & 1 & 0 & 0 & 0 & 7 & 0 & 1 & 0 & 35 & 15 \\
\hline Histiodella holodentata & 0 & 0 & 0 & 0 & 0 & 0 & 0 & 1 & 1 & 0 & 0 & 1 & 2 \\
\hline Histiodella serrata & 0 & 0 & 3 & 0 & 0 & 0 & 0 & 0 & 0 & 0 & 0 & 0 & 0 \\
\hline Histiodella sinuosa & 0 & 0 & 14 & 1 & 0 & 0 & 0 & 0 & 0 & 0 & 0 & 0 & 0 \\
\hline Juanognathus jaanusoni & 0 & 0 & 3 & 0 & 0 & 0 & 0 & 0 & 0 & 0 & 0 & 0 & 0 \\
\hline Microzarkodina hagetiana & 0 & 0 & 1 & 0 & 0 & 0 & 0 & 2 & 0 & 0 & 0 & 5 & 0 \\
\hline Parapaltodus simplicissimus & 2 & 0 & 43 & 8 & 1 & 1 & 0 & 0 & 0 & 0 & 0 & 2 & 1 \\
\hline Paraprioniodus costatus & 0 & 0 & 0 & 0 & 0 & 0 & 0 & 1 & 0 & 0 & 0 & 1 & 0 \\
\hline Paroistodus horridus & 5 & 1 & 36 & 7 & 0 & 2 & 1 & 52 & 12 & 41 & 1 & 202 & 106 \\
\hline Paroistodus horridus secundus & 0 & 0 & 2 & 0 & 0 & 0 & 0 & 0 & 0 & 0 & 0 & 0 & 0 \\
\hline Paroistodus originalis & 0 & 0 & 7 & 1 & 0 & 1 & 0 & 0 & 0 & 1 & 0 & 1 & 0 \\
\hline Periodon macrodentatus & 3 & 1 & 39 & 11 & 2 & 2 & 1 & 13 & 1 & 24 & 1 & 36 & 24 \\
\hline Protopanderodus gradatus & 1 & 1 & 5 & 1 & 0 & 1 & 0 & 0 & 0 & 0 & 0 & 8 & 0 \\
\hline Polonodus sp. & 0 & 0 & 0 & 0 & 0 & 0 & 0 & 0 & 0 & 0 & 0 & 1 & 0 \\
\hline Pteracontiodus cryptodens & 1 & 0 & 2 & 0 & 0 & 0 & 0 & 0 & 0 & 1 & 0 & 1 & 0 \\
\hline Rossodus barnesi & 0 & 0 & 4 & 0 & 0 & 0 & 0 & 0 & 0 & 0 & 0 & 0 & 0 \\
\hline Scolopodus striatus & 0 & 0 & 9 & 0 & 0 & 0 & 0 & 0 & 0 & 0 & 0 & 0 & 0 \\
\hline Semiacontiodus potrerillensis & 1 & 0 & 1 & 0 & 0 & 0 & 0 & 0 & 0 & 0 & 0 & 0 & 0 \\
\hline Venoistodus balticus & 0 & 0 & 0 & 0 & 0 & 0 & 0 & 1 & 0 & 0 & 0 & 2 & 12 \\
\hline Yangtzeplacognathus crassus & 0 & 0 & 3 & 0 & 0 & 0 & 1 & 0 & 0 & 0 & 0 & 0 & 0 \\
\hline
\end{tabular}




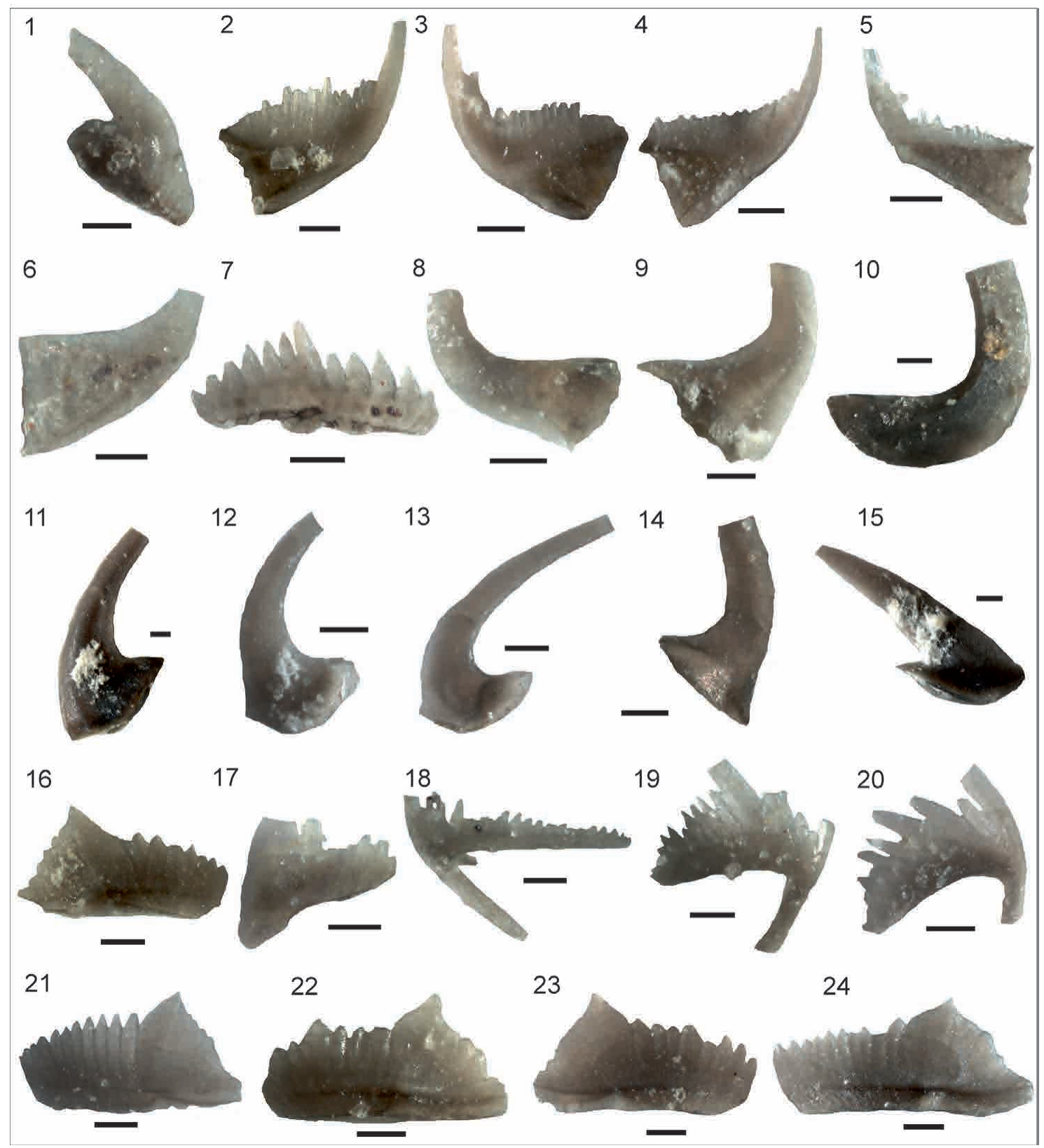

FIG. 4. Conodont species from the San Juan and Gualcamayo formations at the Cerro La Chilca section. 1-6. Ansella jemtlandica (Löfgren); 1. M element, sample G6, CORD-MP 77037; 2. Sa element, sample SJ-1, CORD-MP 77038; 3-4. Sb elements, sample SJ-1, CORD-MP 77039-77040; 5. Sc element, sample G6, CORD-MP 77041; 6. P element, sample G6, CORDMP 77042. 7. "Bryantodina" aff. typicalis Stauffer, Pa element, sample G6, CORD-MP 77043. 8. Cornuodus longibasis Lindström, sample SJ-3, CORD-MP 77044. 9. Dapsilodus sp., Sample SJ-3, CORD-MP 77045. 10. Drepanodus reclinatus (Lindström), Sb element, sample G7, CORD-MP 77046. 11. Drepanoistodus costatus Abaimova, Sb element, sample SJ-1, CORD-MP 77047. 12-13. Drepanodus arcuatus Pander, late forms, sample SJ-1, Sc element, CORD-MP 77048-77049. 14-15. Drepanoistodus tablepointesis Stouge, sample SJ-1; 14. Sc element, CORD-MP 77050; 15. M element, CORD-MP 77051. 16, 21-22. Histiodella serrata Harris, Pa elements, sample SJ-1, CORD-MP 77052-77054. 17-20. Faraheusodus jachalensis Feltes and Albanesi; 17. P element, sample SJ-1, CORD-MP 77055; 18-20. S elements, CORD-MP 77056-77058 (18, 19 : sample G6; 20: sample SJ-1). 23-24. Histiodella sinuosa (Graves and Ellison), Pa element, sample SJ-1, CORD-MP 7705977060. Sacle bar: $0.1 \mathrm{~mm}$ 


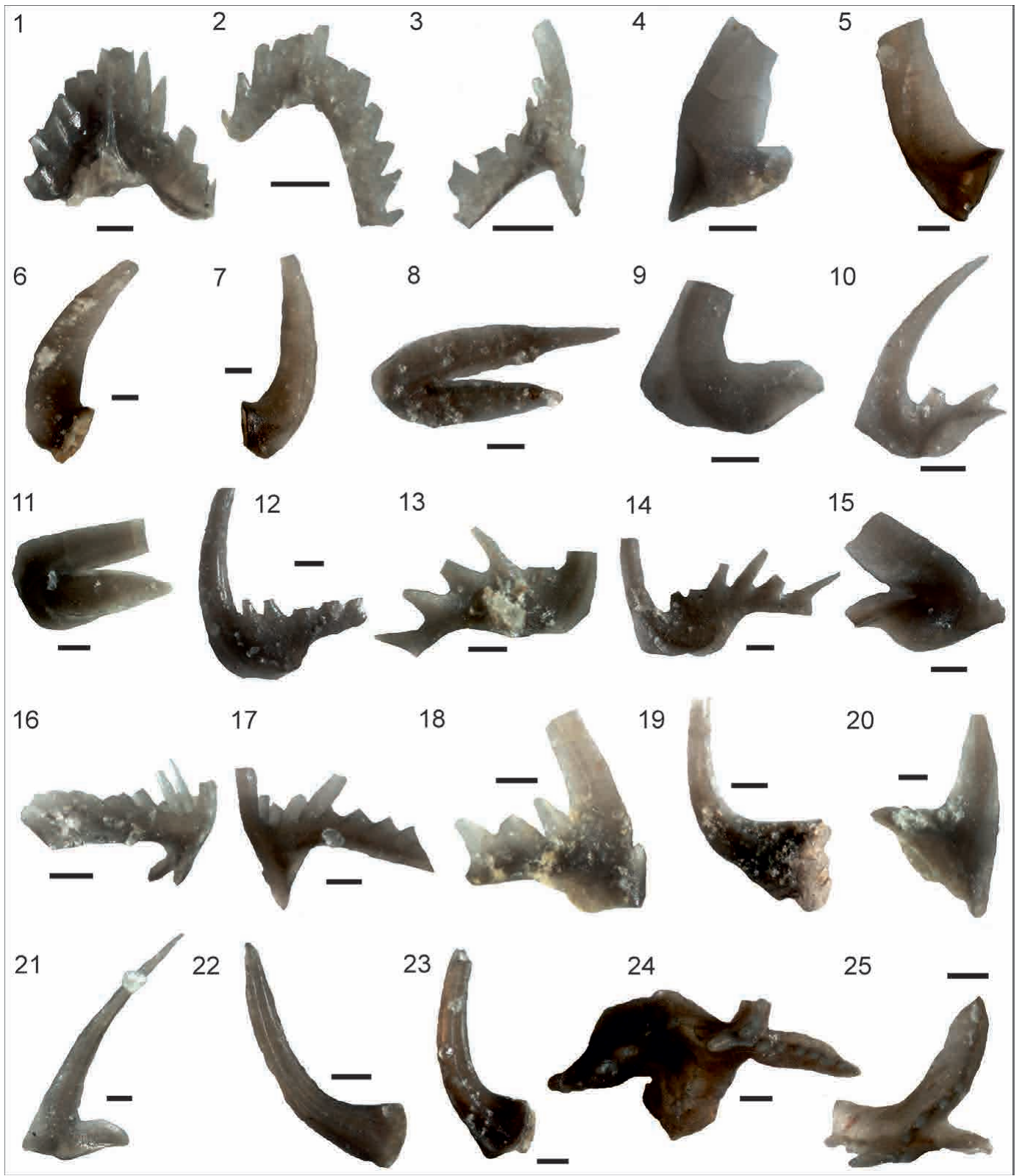

FIG. 5. Conodont species from the San Juan and Gualcamayo formations at the Cerro La Chilca section. 1-3. Microzarkodina hagetiana Stouge and Bagnoli, Sa elements, sample G6, CORD-MP 77061-77063. 4. Costiconus ethingtoni (Fåhræus), M element, sample SJ-1, CORD-MP 77064. 5-7. Parapaltodus simplicissimus Stouge, sample SJ-1; 5. Sc element, CORD-MP 77065; 6. M element, CORD-MP 77066; 7. P element, CORD-MP 77067. 8-9. Paroistodus originalis (Sergeeva), sample SJ-1; 8. M element, CORD-MP 77068; 9. Sa element, CORD-MP 77069. 10. Paroistodus horridus secundus Albanesi, Sc element, sample SJ-1, CORD-MP 77070. 11-14. Paroistodus horridus horridus (Barnes and Poplawski), 11. M element, sample SJ-1, CORD-MP 77071; 12. Sa element, sample G6, CORD-MP 77072; 13. Sc element, sample SJ-1, CORD-MP 77073; 14. P element, sample G6, CORD-MP 77074. 15-18. Periodon macrodentatus (Graves and Ellison), 15. M element, sample SJ-1, CORD-MP 77075; 16. Sa element, sample G7, CORD-MP 77076; 17. Sc element, sample SJ-1, CORD-MP 77077; 18. Pa element, sample G7, CORD-MP 77078. 19. Protopanderodus gradatus Serpagli, Sa element, sample G6, CORD-MP 77079. 20-21. Pteracontiodus cryptodens Mound, sample SJ-1, 20. Sc element, CORD-MP 77080; 21. P element, CORD-MP 77081. 22-23. Scolopodus striatus Pander, sample SJ-1, 22. Sc element CORD-MP 77082; 23. M element CORD-MP 77083. 24-25. Yangtzeplacognathus crassus (Chen and Zhang), sample SJ-1; 24. Pa elements CORD-MP 77084; 25. Pb element CORD-MP 77085. Sacle: $0.1 \mathrm{~mm}$. 


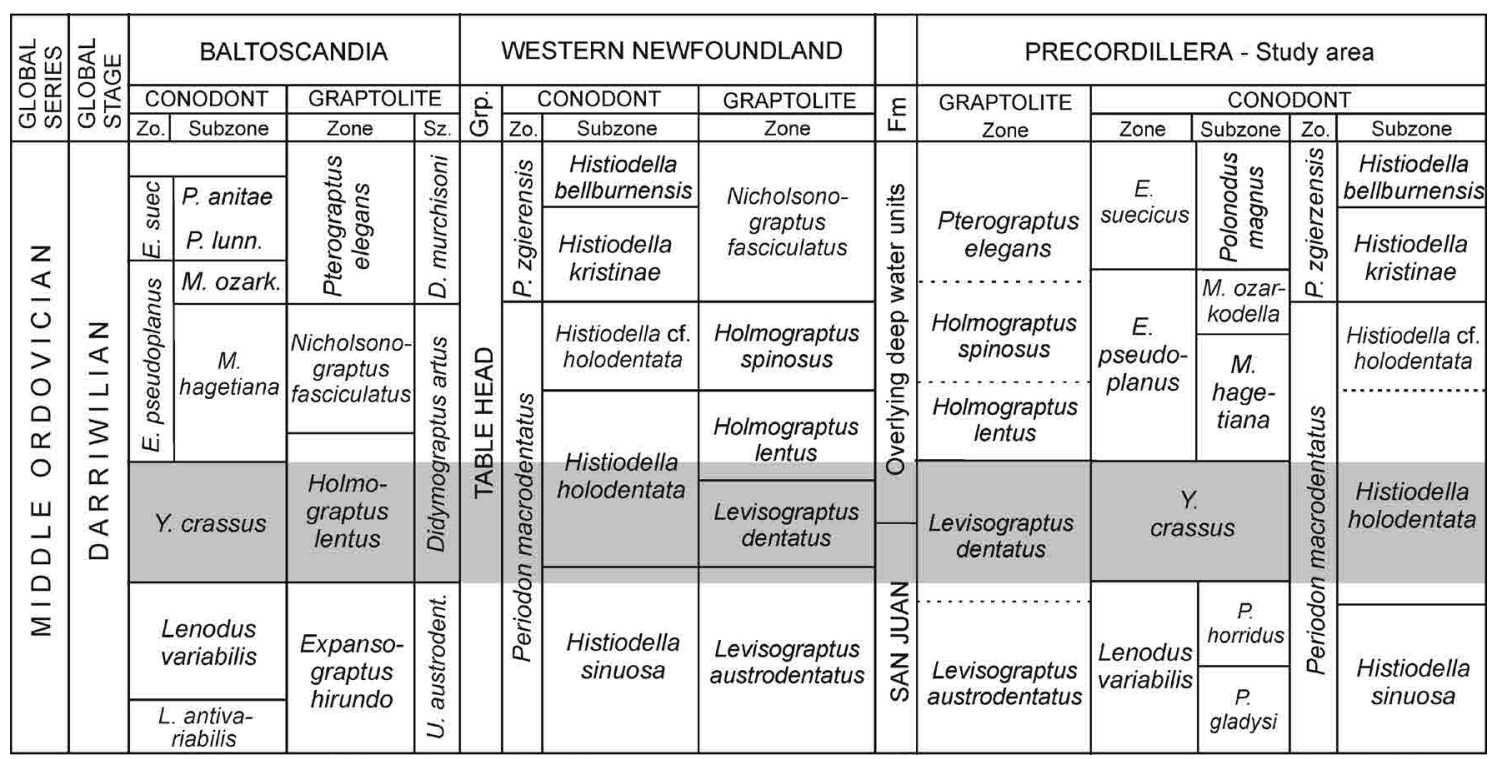

FIG. 6. Biostratigraphic chart of the Middle-Upper Ordovician showing conodont and graptolite zones from Baltoscandia (modified from Löfgren and Zhang, 2003), Western Newfoundland (modified from Stouge, 2012; Maletz, 2009, 2011), Argentine Precordillera (adapted from Feltes et al., 2016; Albanesi and Ortega, 2016 and Serra et al., 2017). Abbreviations: Zo.: Zone; Sz.: Subzone; Grp.: Group; E. suec.: E. suecicus; P. lunn.: P. lunnensis; L. austrodent.: L. austrodentatus.

the Levisograptus dentatus Zone, confirming their mutual biostratigraphic correspondence (Albanesi and Ortega, 2016; Serra et al., 2017).

\subsection{Discussion}

A number of biostratigraphic studies were accomplished in the Cerro La Chilca section. Lehnert (1995) documented the E. suecicus Zone in the upper part of the San Juan Formation according to specimens that he determined as belonging to the eponymous species, from the neighboring Las Chacritas River section, and of ?Histiodella kristinae from strata of the Cerro La Chilca section (see plate 10, figs. 1, 10, 14, of the referred author). However, the specimen illustrated as ?H. kristinae is a fragmentary Pa element (lacking the base and cusp), which cannot be attributed to a particular species of the genus Histiodella. Additionally, the $\mathrm{P}$ elements identified as E. suecicus were reassigned to $Y$. crassus by Löfgren and Zhang (2003), which is consistent with our records. Mestre (2012) published a conodont species range chart from the uppermost San Juan and the Gualcamayo formations (the latter referred to as the Los Azules Formation), where Eoplacognathus pseudoplanus (Viira), Histiodella kristinae (Stouge) and Microzarkodina sp. cf. $M$. ozarkodella (Lindström) are identified from the upper $4 \mathrm{~m}$ of the San Juan Formation and the overlying Gualcamayo Formation, proposing the presence of the upper part of the E. pseudoplanus Zone. However, the Pa element identified as H. kristinae (fig. 5.6, Mestre, 2012) shows a cusp higher than the anterior denticles, being this relation diagnostic for the identification of $H$. holodentata (Stouge, 1984, 2012). Additionally, the stratigraphic range of $H$. sinuosa does not overlap the range of $H$. kristinae, which is a descendant of $H$. holodentata, a succeeding form of $H$. sinuosa (see Stouge, 1984). In a subsequent study, the conodont association obtained from the uppermost strata of the San Juan Formation at this locality ( $1 \mathrm{~m}$ below the contact between the San Juan and Gualcamayo formations) yielded the key species $H$. sinuosa, $P$. horridus and $P$. macrodentatus (Carrera et al., 2013). This association verified an older age by identifying a transitional interval from the upper subzone of the Lenodus variabilis Zone to the succeeding Yangtzeplacognathus crassus Zone, at the top of the San Juan Formation. Recently, Serra et al. (2017) described a rich graptolite fauna assigned to the Levisograptus dentatus Zone (lower middle Darriwilian) in the Gualcamayo Formation 
and the presence of $H$. sinuosa and $Y$. crassus at the top of the San Juan Formation and Y. crassus with $H$. holodentata at the base of the Gualcamayo Formation.

Our sample SJ-1 ( $c a .1 .6 \mathrm{~m}$ below the top of the San Juan Formation, see Fig. 3) yielded conodont elements of $P$. horridus secundus (Fig. 5.10), which would indicate the $P$. horridus Subzone of the L. variabilis Zone of the Argentine general conodont biozonation, as previously suggested by Carrera et al. (2013) and Feltes et al. (2016), and finally revised by Albanesi and Ortega (2016). Although, the co-occurrence of $P$. horridus horridus with $Y$. crassus in the same sample indicates the base of the $Y$. crassus Zone instead. Also, Pa elements of $Y$. crassus are found with $H$. sinuosa in this sample and in the subsequent one ( $1 \mathrm{~m}$ below the top of the San Juan Formation). The latter species is not reported, elsewhere, for the E. pseudoplanus Zone. The rich conodont association including index species such as $Y$. crassus, $M$. hagetiana, $H$. sinuosa, $H$. holodentata and P. macrodentatus, accompanied by the key graptolite species L. dentatus (Figs. 3, 7), verify the actual recognition of the $Y$. crassus Zone for the upper part of the San Juan Formation and the Gualcamayo Formation in the study section.

\subsection{Regional correlation}

The key taxa $Y$. crassus was first recorded in the San Juan Formation at Central Precordillera by Lehnert (1995), although this author identified it as E. suecicus Bergström, and was then documented in numerous works (e.g., Albanesi et al., 2006, 2013; Heredia et al., 2005; Heredia and Mestre, 2011; Mestre and Heredia, 2013; Feltes et al., 2016; Serra et al., 2015, 2017).

Regionally, this zone correlates with coeval strata of the Las Aguaditas Creek section (Feltes et al., 2016), Las Chacritas River section (Heredia et al., 2005; Serra et al., 2015), Cerro Potrerillo (Albanesi et al., 1998), Villicum range (Sarmiento, 1991; Mestre, 2013), Cerro Viejo de Huaco (Ottone et al., 1999; Ortega et al., 2007) and Oculta Creek (Voldman et al., 2013), where the $Y$. crassus Zone is recognized in transitional facies from the San Juan Formation and overlying units. In a recent study, Mango and Albanesi (2018) recognized the L. variabilis Zone in the top strata of the San Juan Formation at the Los Gatos Creek, Cerro Viejo de Huaco area; differing with previous works (Ortega, 1987; Ottone et al., 1999; Ortega et al., 2007) that report the Y. crassus Zone in the stratigraphic sections located towards the south of Cerro Viejo de Huaco. However, the referred authors conclude that this difference is due to a diachronism occurring at the top of the San Juan Formation, where the younger strata ( $Y$. crassus Zone) are exposed in sections located towards the south of the Cerro Viejo de Huaco (Mango and Albanesi, 2018). The conodont fauna associated with $Y$. crassus also allows the correlation with the Yerba Loca Formation at Ancaucha creek (Albanesi et al., 1995; Voldman et al., 2008) and with the Los Sombreros Formation at Los Túneles of Jáchal river (Voldman et al., 2009).

Heredia et al. (2005) reported, with doubt, the presence of $Y$. crassus in the Las Chacritas River section and Albanesi et al. (2006) published the presence of this index species at Cerro Viejo de Huaco. Later, Albanesi et al. (2013) and Serra et al. (2015) verified it's the record across the contact between the San Juan Formation and the overlying Las Chacritas Formation. Mestre (2012), Heredia and Mestre (2011, 2013) and Mestre and Heredia (2013) identified $Y$. crassus in the uppermost meters of the San Juan Formation at the El Aluvión Creek (Cerro Viejo de Huaco area), Cerro La Chilca and in the Las Chacritas River sections. Mestre (2013) identified the Y. crassus Zone through transitional beds between the San Juan and Gualcamayo formations in the Villicum Range. On the other hand, a rich conodont fauna was documented in association with the index species $Y$. crassus and H. holodentata in the upper strata of the San Juan Formation at the Oculta Creek section (Voldman et al., 2013). In a recent study, the first appearance datum of $Y$. crassus was recorded $15 \mathrm{~m}$ below the top of the San Juan Formation at the Las Aguaditas Creek section, delimiting the lower boundary of this biozone, whereas the upper limit is marked by the presence of Dzikodus tablepointensis (Stouge), $19 \mathrm{~m}$ above the base of the Las Aguaditas Formation (Feltes et al., 2016). These authors recognized a similar faunal relationship and recovered elements of $L$. variabilis, $H$. sinuosa, $H$. holodentata and $P$. horridus co-occurring with $Y$. crassus. These faunal relationships are in accordance with those obtained from the Cerro La Chilca, and reinforce the identification of the $Y$. crassus Zone through the uppermost strata of the San Juan Formation and the lower part of the Gualcamayo Formation. 


\subsection{Global correlation}

The presence of Y. crassus in the Cerro La Chilca section is significant for intercontinental correlation, used as an index species in the stratigraphic schemes of Baltoscandia (Löfgren, 2004), South China (Zhang, 1998), and recently incorporated in the biozonal scheme of the Argentine Precordillera (Heredia et al., 2011; Albanesi and Ortega, 2016). The abundance of Histiodella species at the Cerro La Chilca section allow for a precise correlation with western Newfoundland (Stouge, 2012) and North China (Wang et al., 2014; Jing et al., 2016).

The $Y$. crassus Zone is widely recognized in the Baltoscandian Region, for example in Kinnekulle and Gullhögen at Billingen (Zhang, 1997, 1998), Scania (Erlström et al., 2001), Gulf of Bothnia (Löfgren, 1985; Zhang, 1997), Gillberga and Hagudden on Öland (Stouge and Bagnoli, 1990; Zhang, 1997; Löfgren, 2000), southern Gotland (Zhang, 1998) and Estonia (Zhang, 1997; Viira et al., 2001); although, there are exceptions such as Norway, where the species was not recorded (Rasmussen, 2001). Löfgren and Zhang (2003) reported that $Y$. crassus first appearance co-occurs with L. variabilis and it disappears in the basal part of the interval bearing few specimens of $E$. pseudoplanus.

In China, $Y$. crassus appears together with $P$. horridus and $P$. macrodentatus (Chen et al., 2006). The species $P$. macrodentatus is recorded with $H$. holodentata in the Kuniutan Formation of South China (Zhang, 1998), and these species, together with $H$. sinuosa occur in the Dawangou Formation of the Tarim Region (Du et al., 2005). The Y. crassus Zone was also documented in the Kuniutan Formation (Dw2) from the Yichang Region of the Yangtze Platform, South China (Zhang, 1998; Wu et al., 2014).

In western Newfoundland, the $Y$. crassus Zone corresponds to the $P$. macrodentatus Zone, although restricted to the intermediate $H$. holodentata Subzone (Stouge, 2012). The presence of Periodon macrodentatus in the Middle Ordovician strata of the Oslobreen Group (Svalbard Archipelago) allows for correlation with the respective interval of the Laurentian margin (Lehnert et al., 2013), the authors also mention the high abundance of $P$. originalis. Originally, in the Argentine Precordillera, the transitional forms between Paroistodus originalis and $P$. horridus were recorded through the upper part of the L. variabilis Zone, in the lower member of the Gualcamayo Formation at the Cerro Potrerillo section (Albanesi et al., 1998; Albanesi and Barnes, 2000), allowing for the definition of the upper interval of the L. variabilis Zone; namely, the $P$. horridus Subzone (Albanesi and Ortega, 2002). At the Cerro La Chilca section, the record of $P$. originalis, $P$. horridus secundus, and $P$. horridus horridus coexist with $H$. sinuosa in the upper strata of the San Juan Formation suggesting stratigraphically younger strata than observed in the Oslobreen Group.

The conodont fauna from Thompson Creek, New Zealand, is referred to the middle Darriwilian (Zhen et al., 2009), comparable with contemporaneous units of central New South Wales (Zhen and Percival, 2004). The conodont association described by the authors resembles that of the Cerro La Chilca section; namely, $A$. jemtlandica, $C$. longibasis, $D$. cf. reclinatus, $D$. tablepointensis, $P$. simplicissimus, $V$. balticus, $P$. macrodentatus, $H$. holodentata, $P$. originalis and $P$. horridus. The co-occurrence of the latter four species enables correlation of the uppermost strata of the San Juan Formation and the Gualcamayo Formation with the Thompson Creek succession in New Zealand.

\section{Graptolite fauna}

A diverse graptoloid assemblage is recognized in the Gualcamayo Formation at the Cerro La Chilca section (Fig. 7): Acrograptus sp., H. bovis, Holmograptus sp., P. parallelus, X. lofuensis, Xiphograptus sp., Thamnograptus sp., Jiangshanites? sp., Pseudophyllograptus sp., T. bigsbyi, T. quadribrachiatus, A. zhejiangensis, Arienigraptus sp., P. caduceus, Glossograptus sp., P. tentaculatus, L. austrodentatus, L. dentatus, L. primus, L. sinicus and Levisograptus sp. (Serra et al., 2017). This assemblage belongs to the epipelagic and deepwater biotopes; most part of the recorded taxa are pandemic forms but few components are endemic of low paleolatitudes as genus Paraglossogrpatus. Epipelagic biotope is represented principally by biserial Axonophora (genus Levisograptus) and the deep-water biotope is characterized by isograptids and glossograptids (Goldman et al., 2013, and references therein). The documented taxa allow the recognition of the pelagic biofacies defined by Cooper et al. (2012) which represents a diverse graptoloid assemblage in offshore environments.

As referred in Serra et al. (2017), the graptolite assemblage is dominated by the genus Pseudo- 


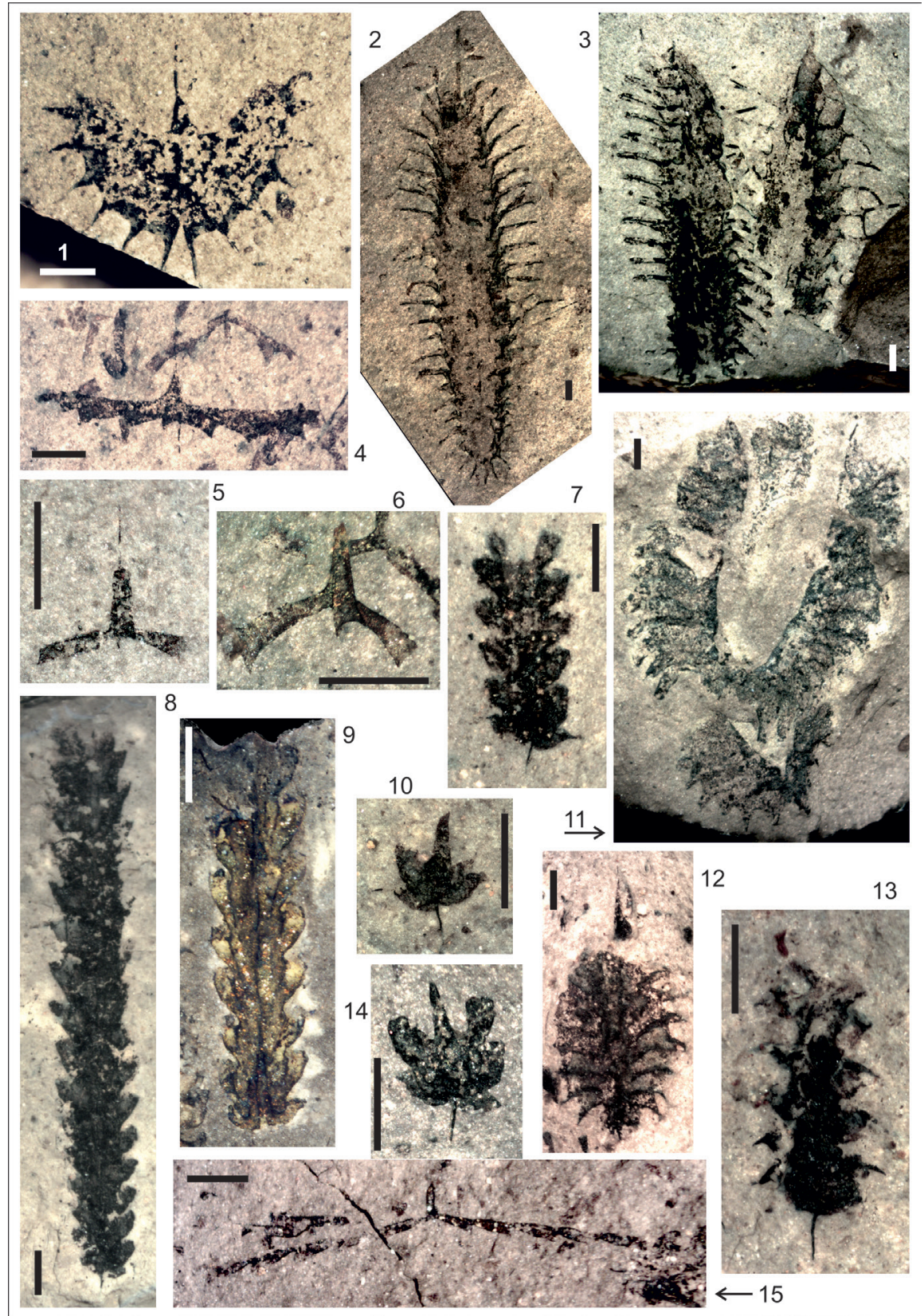

FIG. 7. Graptolites from the Gualcamayo Formation at the Cerro La Chilca section. 1. Arienigraptus zhejiangensis (Yu and Fang), sample G4, CORD-PZ 25778. 2-3. Paraglossograptus tentaculatus Hall; 2. Sample Gf4 (see Serra et al., 2017), CORD-PZ 22272; 3. Sample G4, CORD-PZ 25779; 4. Xiphograptus lofuensis Lee, sample G7, CORD-PZ 22458; 5, 15. Holmograptus bovis Williams and Stevens, sample G75; 5. CORD-PZ 22459; 15. CORD-PZ 25728. 6. Pseudobryograptus parallelus Mu, sample G3, CORD-PZ 25777; 7-8. Levisograptus dentatus (Brongniart), k-bentonite strata between samples G5 and G6 (sample Gf7 in Serra et al., 2017); 7. CORD-PZ 22361; 8. CORD-PZ 22354. 9. Levisograptus austrodentatus (Harris and Keble), kbentonite strata between samples G5 and G6 (sample Gf7 in Serra et al., 2017), CORD-PZ 22443; 10, 14. Levisograptus sp. 10. k-bentonite strata between samples G5 and G6 (sample Gf7 in Serra et al., 2017), CORD-PZ 22384; 14. Sample G7, CORDPZ 22456; 11. Tetragraptus bigsbyi (Hall), sample Gf4 (see Serra et al., 2017), CORD-PZ 25778. 12. Pseudophyllograptus sp. Sample Gf2 (see Serra et al., 2017), CORD-PZ 22221. 13. Levisograptus sinicus Mu and Lee, k-bentonite strata between samples G5 and G6 (sample Gf7 in Serra et al., 2017), CORD-PZ 22328. Scale bar: 1 mm. 
bryograptus in the lower part of the Gualcamayo Formation at the Cerro La Chilca, which decreases to the top where the genus Levisograptus becomes a common component of the fauna and some taxa, such as L. primus, P. caduceus and Pseudophyllograptus sp. appear for the first time. Although environmental conditions are interpreted to be homogeneous through the unit (Henderson et al., 2018), local changes in the taxonomic composition could be the consequence of immigration due to subtle environmental changes in the conditions of the water column, not observed in the lithofacies. Also, in this unit a constant alternation of carbonate and shale is recorded, sea level change could have affected the graptolite assemblages accounting for the local replacement of species.

The lower middle Darriwilian graptolite assemblages present in different sections of the Central Precordillera (Cerro Potrerillo, Cerro Viejo de Huaco, Quebrada Oculta, Quebrada de Las Aguaditas, and Cerro La Chilca sections) contain rich and abundant epi- and mesopelagic components that belong to the pelagic biofacies (sensu Cooper et al., 2012). However, in the different localities a slightly different association of graptolites is developed, which reflects preference to different environmental conditions for graptolite associations. Although these units record the drowning of the carbonate platform, the Los Azules Formation (Cerro Viejo section) and the Gualcamayo Formation (Cerro Potrerillo section) represent deeper depositional environment compared to that of the Las Aguaditas Formation (Las Aguaditas Creek section) and the Gualcamayo Formation (Cerro La Chilca section). It is worth mentioning the diachronous nature of the Gualcamayo Formation, where the black shales from the base of the middle member in the Cerro Potrerillo section (north of Precordillera) are equivalent in age to the alternating carbonate and black laminated shale unit in the Cerro La Chilca section (to the south in the Central Precordillera).

In the Oculta Creek, Los Cauquenes Range, the lower member of the Los Azules Formation is dominated by $T$. acanthonotus, and to a lesser extent by $P$. ensiformis and $A$. zhejiangensis, the first two species absent in the Las Aguaditas Formation and the Gualcamayo Formation (Cerro La Chilca section). Also, Isograptus divergens Harris and Brachiograptus etaformis Harris and Keble are only present in the Los Azules Formation, indicating deeper-water environments. On the other hand, P. parallelus is particularly abundant in the Gualcamayo Formation of the Cerro La Chilca. The species Cryptograptus antennarius (Hall) was documented in the Los Azules and Las Aguaditas formations and $C$. cf. antennarius in the lower member of the Gualcamayo Formation at Cerro Potrerillo section. The scheme of figure 8 represents the spatial arrangement of the main genera of lower middle Darriwilian graptolites in the in the Cerro La Chilca section and other areas of the Central Precordillera. As in the Cerro La Chilca section, the early middle Darriwilian graptolite assemblages in other sections of the Central Precordillera belong to the epipelagic and deep-water biotopes, preserved in outer-shelf facies.

\section{Concluding Remarks}

A diverse conodont association was recovered from the uppermost San Juan Formation and the Gualcamayo Formation exposed at the Cerro La Chilca classical locality. The presence of Paroistodus horridus horridus, $Y$. crassus and $H$. sinuosa allows constraining the top of the San Juan Formation to the base of the $Y$. crassus Zone of the Baltic scheme and to the $H$. sinuosa Subzone of the P. macrodentatus Zone of the North American scheme. In the overlying Gualcamayo Formation the co-existence of $Y$. crassus with $H$. holodentata enable the recognition of the $Y$. crassus Zone and the H. holodentata Subzone of the $P$. macrodentatus Zone of the relative schemes.

The identification of the $Y$. crassus Zone, as well as the $H$. sinuos $a$ and $H$. holodentata subzones enable the correlation between the study interval with coeval strata at the Las Aguaditas Creek section, Las Chacritas River section, Cerro Potrerillo section, Villicum range, Cerro Viejo de Huaco, Oculta Creek, with the Yerba Loca Formation at Ancaucha creek, and with the Los Sombreros Formation at Los Túneles of Jáchal river, and globally with Baltoscandia, China, western Newfoundland, New Zealand and New South Wales.

A graptolite assemblage belonging to the epipelagic and deep-water biotopes with some components restricted to low paleolatitudes is recognized. This diverse assemblage belongs to the pelagic biofacies, in coherence with the offshore sedimentation environment suggested for the Gualcamayo Formation at the Cerro La Chilca. The local changes observed in the taxonomic 


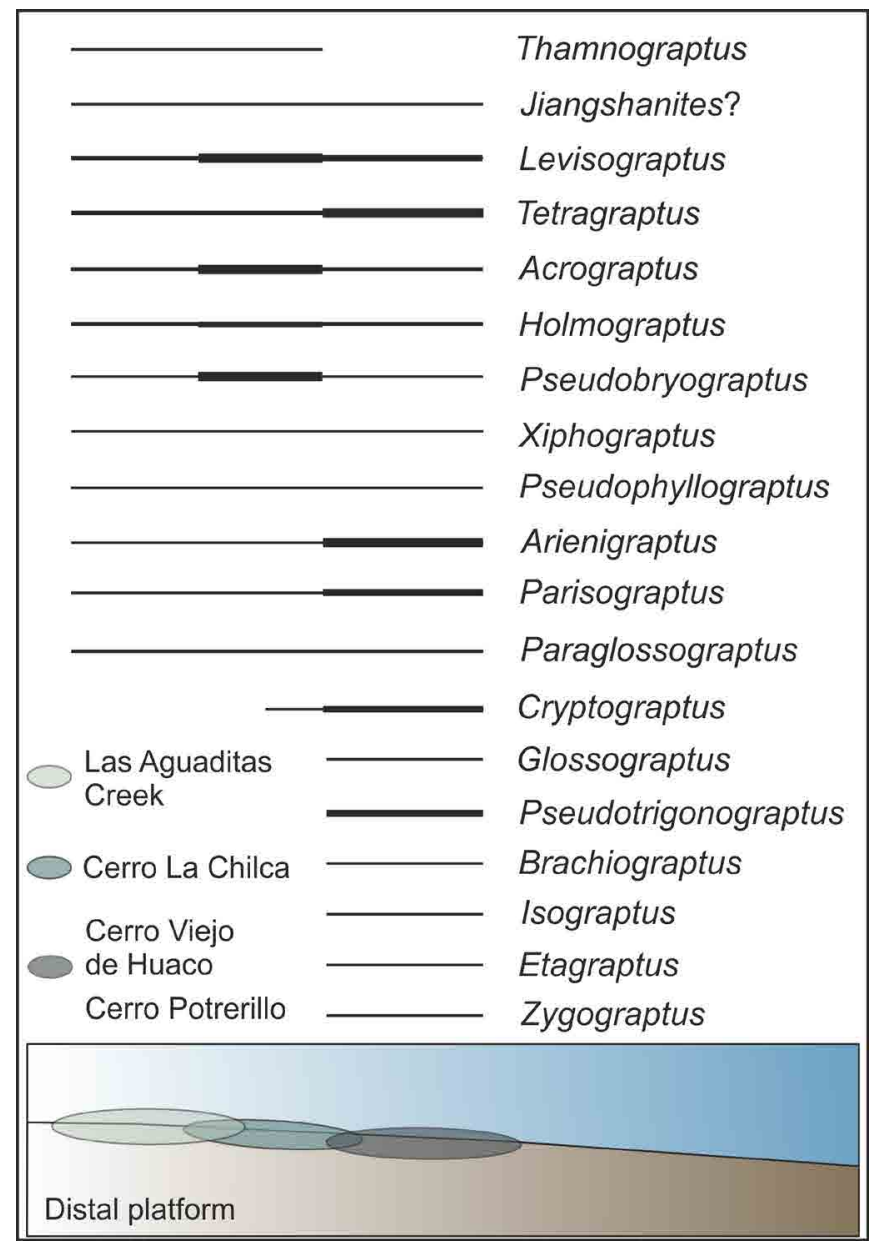

FIG. 8. Scheme showing the distribution of the graptolite genera documented along the distal platform in different areas from the Central Precordillera (Cerro Potrerillo, Oculta Creek, Cerro Viejo de Huaco, Las Aguaditas Creek and Cerro La Chilca sections). Thickness of lines represents the relative abundance of the genera. Figure adapted from Boucot and Chen (2009).

composition along this unit could be the consequence of immigration due to environmental changes in the conditions of the water column, not observed in the lithofacies. On the other hand, the constant alternations of carbonate and shale of this formation driven by sea level change, could also affect the graptolite assemblages accounting for the local replacement of the graptolite species.

Slight differences in the taxonomical composition of different study localities from the Central Precordillera supports the preference of certain associations for particular environments. Graptolites are more diverse in the lower member of the Los Azules Formation, in black shales facies that represent a deeper environment, in relation to the calcareous-shale facies of the Gualcamayo and Las Aguaditas formations of the Cerro La Chilca and Las Aguaditas Creek, respectively.

\section{Acknowledgments}

We wish to acknowledge supporting facilities of the Consejo Nacional de Investigaciones Científicas y Técnicas (in particular PUE 2016 CONICET-CICTERRA), Universidad Nacional de Córdoba, Centro de Investigaciones Geológicas Aplicadas CIGEA (FCEFyN-UNC) and the Museo de Paleontología (FCEFyN-UNC). Editor Waldo Vivallo Sandoval and an anonymous reviewer provided useful comments that improved this contribution. Financial support for this study was provided by PIP-CONICET (2014-2016) to GLA. 


\section{References}

Albanesi, G.L.; Barnes, C.R. 2000. Subspeciation within a punctuated equilibrium evolutionary event: phylogenetic history of the lower-middle Ordovician Paroistodus originalis-P. horridus complex (Conodonta). Journal of Paleontology 74 (3): 492-502.

Albanesi, G.L.; Ortega, G. 2002. Advances on conodontgraptolite biostratigraphy of the Ordovician System of Argentina. In Aspects of the Ordovician System in Argentina (Aceñolaza, F.G.; editor). Serie Correlación Geológica 16, INSUGEO: 143-165. Tucumán.

Albanesi, G.L.; Ortega, G. 2016. Conodont and Graptolite Biostratigraphy of the Ordovician System of Argentina. In Stratigraphy \& Timescales (Montenari, M.; editor): 61-121.

Albanesi, G.L.; Ortega, G.; Hünicken, M.A. 1995. Conodontes y graptolitos de la Formación Yerba Loca (Arenigiano-Llandeiliano) en las quebradas de Ancaucha y El Divisadero, Precordillera de San Juan, Argentina. Boletín Academia Nacional de Ciencias Córdoba 60 (3-4): 365-400.

Albanesi, G.L.; Hünicken, M.; Barnes, C. 1998. Bioestratigrafía de conodontes de las secuencias ordovícicas del cerro Potrerillo, Precordillera Central de San Juan, R. Argentina. Academia Nacional de Ciencias Córdoba, Actas 12: 7-72.

Albanesi G.L.; Voldman, G.G.; Ortega, G. 2006. Control ambiental en la distribución de conodontes de la Zona de Lenodus variabilis (Darriwiliano) en la Precordillera del oeste argentino. In Congreso Argentino de Paleontología y Bioestratigrafía, No. 9, Academia Nacional de Ciencias, Resúmenes: 150 p. Córdoba.

Albanesi, G.L.; Bergström, S.M.; Schmitz, B.; Serra, F.; Feltes, N.A.; Voldman, G.G.; Ortega, G. 2013. Darriwilian (Middle Ordovician) $\delta^{13} \mathrm{C}_{\text {carb }}$ chemostratigraphy in the Precordillera of Argentina: Documentation of the middle Darriwilian Isotope Carbon Excursion (MDICE) and its use for intercontinental correlation. Palaeogeography, Palaeoclimatology, Palaeoecology 389: 48-63.

Astini. R.A.; Ramos, V.A.; Benedetto, J.L.; Vaccari, N.E.; Cañas, F.L. 1996. La Precordillera: Un terreno exótico a Gondwana. In Congreso Geológico Argentino, No. 13 y Congreso de Exploración de Hidrocarburos, No. 3, Actas 5: 293-324.

Astini, R.A.; Benedetto, J.L. 1992. El Ashgilliano tardío (Hirnantiano) del cerro La Chilca, Precordillera de San Juan, Argentina. Ameghiniana 29: 249-264.

Astini, R.A.; Maretto, H.M. 1996. Análisis estratigráfico del Silúrico de la Precordillera Central de San Juan y consideraciones sobre la evolución de la cuenca. In Congreso Geológico Argentino, No. 13 y Congreso de Exploraciones e Hidrocarburos, No. 3, Actas 1: 351-368. Buenos Aires.

Baldis, B.A.J.; Beresi, M.S.; Bordonaro, O.L.; Vaca, A. 1982. Síntesis evolutiva de la Precordillera Argentina. In Congreso Latinoamericano de Geología, No. 5, Actas 4: 300-445. Buenos Aires.

Benedetto, J.L. (ed.) 2003. Ordovician fossils of Argentina. Secretaría de Ciencia y Técnica, Universidad Nacional de Córdoba: 560 p.

Benedetto, J.L. 2010. Placas de macaeridios (Annelida) en pelitas negras del Ordovícico Medio de la Precordillera de San Juan, Argentina. In Congreso Argentino de Paleontología y Bioestratigrafía, No. 10, y Congreso Latinoamericano de Paleontología, No. 7, Resúmenes: 137. La Plata.

Blasco, G.; Ramos, V. 1976. Graptolitos caradocianos de la Formación Yerba Loca y del cerro La Chilca, Departamento Jáchal, Provincia de San Juan. Ameghiniana 13 (3-4): 312-329.

Boucot, A.J.; Chen, X. 2009. Fossil plankton depth zones. Palaeoworld 18: 213-234.

Bracaccini, O. I. 1950. Observaciones estratigráficas en la Precordillera sanjuanina. Revista Asociación Geológica Argentina 5: 4-14.

Carrera, M.G. 1997. Significado paleoambiental de los poríferos y briozoos de la Formación San Juan (Ordovícico), Precordillera Argentina. Ameghiniana 34 (2): 179-199.

Carrera, M.G.; Fenoglio, F.; Albanesi, G.L.; Voldman, G. 2013. Conodonts sequence stratigraphy and the drowning of the San Juan carbonate platform in the Ordovician of the Argentine Precordillera. In Conodonts from the Andes International Conodont Symposium (Albanesi G.L.; Ortega, G.; editors). Asociación Paleontológica Argentina 3: 5-12. Buenos Aires.

Chen, X.; Zhang, Y.D.; Bergström, S.M.; Xu, H.G. 2006. Upper Darriwilian graptolite and conodont zonation in the global stratotype section of the Darriwilian stage (Ordovician) at Huangnitang, Changshan, Zhejiang, China. Palaeoworld 15: 150-170.

Cooper, R.A.; Rigby, S.; Loydell, D.K.; Bates, D.E. 2012. Palaeoecology of the Graptoloidea. Earth Science Reviews 112: 23-41.

Cuerda, A.J. 1965. Monograptus leintwardinensis var. incipiens Wood en el Silúrico de la Precordillera. Ameghiniana 4 (5): 171-177.

Cuerda, A.J. 1969. Sobre las graptofaunas del Silúrico de San Juan. Ameghiniana 6: 223-235. 
Cuerda, A.J. 1973. Sobre la presencia de Zygograptus sp. (Graptolithia) en la Formación Gualcamayo, Ordovícico de San Juan-La Rioja. Ameghiniana 10 (2): 1991-195.

Cuerda, A.J. 1986. Graptolitos del techo de la Formación San Juan, Precordillera de San Juan. In Congreso Argentino de Paleontología y Bioestratigrafía, No. 48: 49-57.

Cuerda, A.; Furque, G. 1985. Graptolitos del techo de la Formación San Juan, Precordillera de San Juan. In Jornadas de Geología de la Precordillera de San Juan 1: 113-118.

Du, P.D.; Zhao, Z.X.; Huang, Z.B.; Tan, Z.J.; Wang, C.; Yang, Z.1.; Zhang, G.Z.; Xiao, J.N. 2005. Discussion on four conodont species of Histiodella from Tarim Basin and their stratigraphic implication. Acta Micropalaeontologica Sinica 22: 357-369.

Erlström, M.; Ahlberg, P.; Löfgren, A. 2001. Lower Palaeozoic stratigraphy at Lyby and Tängelsås, central Scania, southern Sweden. GFF 123: 7-14

Epstein, A.G.; Epstein, J.B.; Harris, L.D. 1977. Conodont Color Alteration-an Index to Organic Metamorphism. U.S. Geological Survey Professional Paper 995: 1-27.

Feltes, N.A.; Albanesi, G.L.; Bergström, S.M. 2016. Conodont biostratigraphy and global correlation of the middle Darriwilian-lower Sandbian Las Aguaditas Formation, Precordillera of San Juan, Argentina. Andean Geology 43 (1): 60-85.

Furque, G. 1983. Descripción geológica de la Hoja 19c, Ciénaga de Gualilán, San Juan. Servicio Geológico Nacional, Boletín 193: 106 p. Buenos Aires.

Furque, G.; Cuerda, A. 1979. Ordovícico argentino. Asociación Geológica Argentina, Publicación Especial, serie B (Didáctica y Complementaria) 7: 1-56.

Goldman, D.; Maletz, J.; Melchin, M.J.; Junxuan, F. 2013. Chapter 26: Graptolite paleobiogeography. In Early Palaeozoic Biogeography and Palaeogeography (Harper, D.A.T.; Servais, T.; editors). Geological Society, Memoirs 38: 415-428. London.

Henderson, M.A.; Serra, F.; Feltes, N.A.; Albanesi, G.L.; Kah, L.C. 2018. Paired isotope records of carbonate and organic matter from the Middle Ordovician of Argentina: Intrabasinal variation and effects of the marine chemocline. Palaeogeography, Palaeoclimatology, Palaeoecology 490: 107-130.

Heredia, S.; Mestre, A. 2011. Middle Darriwilian Conodont Biostratigraphy in the Argentine Precordillera. In Ordovician of the World (Gutiérrez Marco, J.C.; Rábano, I.; García Bellido, D.; editors). Cuadernos del Museo Geominero 14: 229-234.
Heredia, S.; Mestre, A. 2013. Advances in the middle Darriwilian conodont biostratigraphy of the Argentine Precordillera. In Conodonts from the AndesInternational Conodont Symposium (Albanesi, G.L.; Ortega, G.; editors). Asociación Paleontológica Argentina, Special Publication 3 (13): 45-47. Buenos Aires.

Heredia, S.E.; Beresi, M.; Peralta, S. 2005. Darriwilian conodont biostratigraphy of the Las Chacritas Formation, Central Precordillera (San Juan Province, Argentina). Geologica acta 3 (4): 385-394.

Heredia, S.E.; Beresi, M.; Peralta, S. 2011. Estratigrafía y bioestratigrafía del Ordovícico Medio del río Las Chacritas, Precordillera Central de San Juan. Serie Correlación Geológica 27 (1): 18-26.

Jing, X.C.; Zhou, H.R.; Wang, X.L. 2016. Biostratigraphy and biofacies of the Middle Darriwilian (Ordovician) conodonts from the Laoshidan section in the western margin of the North China Craton. Marine Micropaleontology 125: 51-65.

Keller, M. 1999. Argentine Precordillera. Sedimentary and Plate Tectonic History of a Laurentian Crustal Fragment in South America. Geological Society of America, Special Paper 341: 131 p.

Lehnert, O. 1995. Ordovizische Conodonten aus der Präkordillere Westargentiniens: Ihre Bedeutung für Stratigraphie und Paläogeographie. Erlanger Geologische Abhandlungen 125: 1-193.

Lehnert, O.; Stouge, S.; Brandl, P.A. 2013. Conodont biostratigraphy in the Early to Middle Ordovician strata of the Oslobreen Group in Ny Friesland, Svalbard. Zeitschrift der Deutschen Gesellschaft für Geowissenschaften. German J. Geoscience 164 (1): 149-172.

Löfgren, A.M. 1985. Early Ordovician conodont biozonation at Finngrundet, south Bothnian Bay, Sweden. Geology of the southern Bothnian Sea. Part III. Bulletin of the Geological Institutions of the University of Uppsala, N.S. 10: 115-128.

Löfgren, A.M. 2000. Early to early Middle Ordovician conodont biostratigraphy of the Gillberga quarry, northern Öland, Sweden. GFF 122: 321-338.

Löfgren, A.M. 2004. The conodont fauna in the Middle Ordovician Eoplacognathus pseudoplanus Zone of Baltoscandia. Geological Magazine 141 (4): 505-524.

Löfgren, A.M.; Zhang, J. 2003. Elements association and morphology in some Middle Ordovician platformequipped conodonts. Journal of Paleontology 77 (4): 721-737.

Maletz, J. 2009. Holmograptus spinosus and the Middle Ordovician (Darriwilian) graptolite biostratigraphy at 
Les Méchins (Quebec), Canada. Canadian Journal of Earth Sciences 46 (10): 739-755.

Maletz, J. 2011. The identity of the Ordovician (Darriwilian) graptolite Fucoides dentatus Brongniart, 1828. Palaeontology 54 (4): 851-865.

Mango, M.J.; Albanesi, G.L. 2018. Bioestratigrafía y provincialismo de conodontes del tramo mediosuperior de la Formación San Juan en el cerro Viejo de Huaco, Precordillera, Argentina. Andean Geology 45 (2): 274-299. doi: 10.5027/andgeoV45n2-3056.

Mestre, A. 2012. Bioestratigrafía de conodontes del techo de la Formación San Juan y el miembro inferior de la Formación Los Azules, cerro La Chilca, Precordillera Central. Ameghiniana 49 (2): 185-197.

Mestre, A. 2013. Middle Darriwilian conodont biostratigraphy of the Villicum Range, Eastern Precordillera, Argentina. In Conodonts from the Andes-International Conodont Symposium (Albanesi, G.L.; Ortega, G.; editors). Special Publication 3 (13): 69-72. Asociación Paleontológica Argentina. Buenos Aires.

Mestre, A.; Heredia, S. 2013. Biostratigraphic significance of Darriwilian conodonts from Sierra de La Trampa (Central Precordillera, San Juan, Argentina). Geosciences Journal 17 (1): 43-53.

Ortega, G. 1987. La graptofauna y conodontes de la Formación LosAzules, Cerro Viejo, Zona de Huaco, Departamento Jáchal, San Juan. Doctoral thesis. FCEFyN, Universidad Nacional de Córdoba 2T: 1-109.

Ortega, G. 2010. Primeros registros de Machaeridias (Annelida) en el Ordovícico Medio y Superior de Argentina. In Congreso Argentino de Paleontología y Bioestratigrafía, No. 10 y Congreso Latinoamericano de Paleontología, No. 7, Resúmenes: 1-52. La Plata.

Ortega, G.; Albanesi, G.L.; Frigerio, S.E. 2007. Graptoliteconodont biostratigraphy and biofacies of the Middle Ordovician Cerro Viejo succession, San Juan Precordillera, Argentina. Palaeogeography, Palaeoclimatology, Palaeoecology 245: 245-263.

Ortega, G.; Albanesi, G.L.; Zeballo, F.J. 2013. Machaeridians from the Middle and Upper Ordovician of the Argentine Precordillera. Geological Journal 48: 212-221.

Ottone, E.G.; Albanesi, G.L.; Ortega, G.; Holfeltz, G.D. 1999. Palynomorphs, conodonts and associated graptolites from the Ordovician Los Azules Formation, Central Precordillera, Argentina. Micropaleontology 45: 225-250.

Padula, E.; Rolleri, E.; Mingramm, A.; Roque Criado, P.; Flores, M.A.; Baldis, B. 1967. Devonian of Argentina. Proceedings International Symposium. Dev. Syst. 2: 165-199. Calgary.
Peralta, S.H. 1998. Graptolites of the $N$. gracilis Zone in the black shale sequences of the San Juan Precordillera, Argentina: its biostratigraphic and paleoenvironmental significance. In Proceedings of the Sixth International Graptolite Conference of the GWG (IPA) and the SW Iberia Field Meeting of the International Subcommission on Silurian Stratigraphy (ICS-IUGS) (GutiérrezMarco, J.C.; Rábano, I.; editors). Instituto Tecnológico Geominero de España 23: 244-247. Madrid

Peralta, S.H. 2003. Ordovician and Silurian of the Precordillera, San Juan Province, Argentina. In Field Trip Guide International Symposium on the Ordovician System, No. 9 y International Graptolite Conference and Field Meeting of the Subcomission on Silurian Stratigraphy, No. 7 (Peralta, S.H.; Albanesi, G.L.; Ortega G.; editors). Serie Correlación Geológica 10: 23-43. Tucumán.

Rasmussen, J.A. 2001. Conodont biostratigraphy and taxonomy of the Ordovician shelf margin deposits in the Scandinavian Caledonides. Fossils and Strata 48: $1-180$.

Sánchez, T.; Carrera, M.; Benedetto, J.L. 1996. Variaciones faunísticas en el techo de la Formación San Juan (Ordovícico temprano, Precordillera Argentina): Significado paleoambiental. Ameghiniana 33 (2): 185-200.

Sarmiento, G.N. 1991. Conodontos de la Zona de E. suecicus (Llanvirniano inferior) en la sierra de Villicum, Precordillera de San Juan, Argentina. Revista Española de Micropaleontología 23 (3): 113-132.

Serra, F.; Albanesi, G.L.; Ortega, G.; Bergström, S.M. 2015. Biostratigraphy and palaeoecology of MiddleLate Ordovician conodont and graptolite faunas of the Las Chacritas River section, Precordillera of San Juan, Argentina. Geological Magazine 152 (5): 813-829.

Serra, F.; Feltes, N.A.; Ortega, G.; Albanesi, G.L. 2017. Lower middle Darriwilian (Ordovician) graptolites and index conodonts from the Central Precordillera of San Juan Province, Argentina. Geological Journal 53: 2161-2177.

Serra, F.; Feltes, N.A.; Albanesi, G.L.; Goldman, D. 2019. High-resolution conodont biostratigraphy from the Darriwilian Stage (Middle Ordovician) of the ArgentinePrecordillera and biodiversity analyses: a CONOP9 approach. Lethaia 52: 188-203.

Stappenbeck, R. 1910. La Precordillera de San Juan y Mendoza. Ministerio de Agricultura de la Nación, sección Geología, Anales 4 (4): 1-187. Buenos Aires.

Stelzner, A. 1873. Mitteinlungen an Professor H.B. Geinitz. Ubre seine Reise durch die Argentinischen Provinzen 
San Juan und Mendoza und die Cordillere zwischen dem $31^{\circ}$ und $32^{\circ} \mathrm{S}$. Neues Jahrbuch für Mineralogie, Geologie und Palaeontologie: 726-744.

Stone, J. 1987. Review of investigative techniques used in the study of conodonts. In Conodonts: Investigative Techniques and Applications (Austin, R.L.; editor). Ellis Horwood Limited: 17-34. Chichester.

Stouge, S. 1984. Conodonts of the Middle Ordovician Table Head Formation, western Newfoundland. Fossils and Strata 16: 1-145.

Stouge, S. 2012. Middle Ordovician (late DapingianDarriwilian) conodonts from the Cow Head Group and Lower Head Formation, western Newfoundland, Canada. Canadian Journal of Earth Sciences 49 (1): 59-90.

Stouge, S.; Bagnoli, G. 1990. Lower Ordovician (VolkhovianKundan) conodonts from Hagudden, northern Öland, Sweden. Palaeontographia Italica 77: 1-54.

Tortello, M.F.; Peralta, S.H. 2004. Trilobites del miembro inferior de la Formación Gualcamayo (Llanvirniano temprano) en el cerro La Chilca, Precordillera de San Juan, Argentina. Boletín Geológico y Minero 115: 665-682.

Viira, V.; Löfgren, A.; Mägi, S.; Wickström, J. 2001. An Early to Middle Ordovician succession of conodont faunas at Mäekalda, northern Estonia. Geological Magazine 138: 699-718.

Voldman, G.G.; Albanesi, G.L.; Do Campo, M. 2008. Conodont palaeothermometry of contact metamorphism -metasomatism in middle Ordovician rocks from the Precordillera of western Argentina. Geological Magazine 145 (3): 449-462.

Voldman, G.G.; Albanesi, G.L.; Ramos, V.A. 2009. Ordovician metamorphism in the carbonate platform of the Argentine Precordillera: implications for the geotectonic evolution of the proto-Andean margin of Gondwana. Geology 37 (4): 311-314.

Voldman, G.G.; Ortega, G.; Albanesi, G.L. 2013. Middle Ordovician conodonts and graptolites at Los Cauquenes Range, Central Precordillera of San Juan, Argentina. In Conodonts from the Andes-International Conodont Symposium (Albanesi, G.L.; Ortega, G.; editors). Asociación Paleontológica Argentina. Special Publication 3 (13): 117-121. Buenos Aires.

Wang, Z.H.; Bergström, S.M.; Zhen, Y.Y.; Zhang, Y.D.; Wu, R.C., 2014. A revision of the Darriwilian biostratigraphic conodont zonation in Tangshan, Hebei Province based on new conodont collections. Acta Palaeontol. Sin. 53: 1-15.

Wu, R.C.; Stouge, S.; Percival, I.G.; Zhan, R.B. 2014. Early-Middle Ordovician conodont biofacies on the Yangtze Platform margin, South China: Applications to palaeoenvironment and sea-level changes. Journal of Asian Earth Sciences 96: 194-204.

Zhang, J. 1997. The Lower Ordovician conodont Eoplacognathus crassus Chen y Zhang, 1993. GFF 119: 61-65.

Zhang, J. 1998. Conodonts from the Guniutan Formation (Llanvirnian) in Hubei and Hunan Provinces, southcentral China. Stockholm Contributions in Geology 46: 1-161.

Zhen, Y.Y.; Percival, I.G. 2004. Darriwilian (Middle Ordovician) conodonts from the Weemalla Formation, south of Orange, New South Wales. Memoirs of the Association of Australasian Palaeontologists 30: 153-178.

Zhen, Y.Y.; Percival, I.G.; Cooper, R.A.; Simes, J.E.; Wright, A.J. 2009. Darriwilian (Middle Ordovician) conodonts from Thompson Creek, Nelson Province, New Zealand. Memoirs of the Association of Australasian Palaeontologists 37: 25-53.

Manuscript received: August 16, 2018; revised/accepted: February 22, 2019; available online: September 30, 2019. 